\title{
Efektivitas Penggunaan Media Sosial dalam Pemasaran Rumah Sakit: Systematic Review
}

\author{
Muhammad Fahriza ${ }^{1}$, Pujiyanto ${ }^{2}$ \\ ${ }^{1}$ Program Pasca Sarjana Kajian Administrasi Rumah Sakit, Fakultas Kesehatan Masyarakat \\ Universitas Indonesia \\ ${ }^{2}$ Departemen Administrasi dan Kebijakan Kesehatan Fakultas Kesehatan Masyarakat \\ Indonesia
}

\begin{abstract}
Abstrak
Latar Belakang : Pada awal tahun 2020, jumlah pengguna media sosial di seluruh dunia telah melampaui angka 3,8 miliar. Banyak organisasi layanan kesehatan menggunakan media sosial. Pada tahun 2014, 94\% rumah sakit menggunakan media sosial. Saat ini, jumlah rumah sakit yang menggunakan media sosial untuk komunikasi dan pemasaran semakin meningkat. Tujuan studi ini adalah untuk mengkaji penggunaan media sosial dalam bidang pemasaran di rumah sakit.

Metode: Kajian sistematis ini menggunakan metode PRISMA, mengkaji artikel yang dipublikasi tahun 2016 2020. Sumber artikel penelitian mengenai penggunaan media sosial dalam bidang pemasaran di rumah sakit didapatkan dengan pencarian menggunakan kata kunci "social media" dikombinasikan dengan kata kunci "hospital" dan "marketing" atau "hospital marketing" dan melalui database pencarian Google Scholar dan PubMed. Mendeley digunakan untuk menyusun dan mengevaluasi judul beserta abstrak, mengidentifikasi dan menghapus artikel yang ganda.

Hasil: Sebanyak 13 artikel dipilih untuk kajian sistematis. Hasilnya diklasifikasikan dan dilaporkan berdasarkan dua kategori, yaitu jenis platform dan efektivitasnya berupa manfaat dari penggunaannya. Jenis platform yang paling sering digunakan adalah Facebook kemudiaan diikuti dengan Twitter dan Instagram. Sedangkan manfaat terpenting adalah pengembangan strategi pemasaran (marketing) yang optimal.

Kesimpulan: Platform media sosial telah menjadi keharusan bagi suatu rumah sakit untuk pemasaran dan promosi saat ini serta mampu menciptakan brand image secara global terkait efektivitas penggunaannya yang dapat mempengaruhi reputasi rumah sakit.
\end{abstract}

Kata Kunci: marketing, rumah sakit, brand building

\section{Effectiveness of Use of Social Media Inmarketing Hospital: Systematic Review}

\footnotetext{
Abstract

Background: At the beginning of 2020, the number of social media users worldwide has surpassed the 3.8 billion mark. Many health care organizations use social media. In 2014, 94\% of hospitals used social media. Currently, the number of hospitals using social media for communication and marketing is increasing. The purpose of this study is to examine the use of social media in marketing in hospitals.

Methods: This systematic study uses the PRISMA method, reviewing articles published in 2016 - 2020. Sources of research articles on the use of social media in the field of marketing in hospitals are obtained by searching using the keyword "social media" combined with the keywords "hospital" and "marketing" or "hospital marketing. "And through the Google Scholar and PubMed search databases. Mendeley was used to compile and evaluate titles and abstracts, to identify and remove duplicate articles.

Results: A total of 13 articles were selected for a systematic review. The results are classified and reported based on two categories, namely the type of platform and its effectiveness in the form of benefits from its use. The type of platform most often used is Facebook followed by Twitter and Instagram. Meanwhile, the most important benefit is the development of an optimal marketing strategy.

Conclusion: Social media platforms have become a must for hospitals for marketing and promotion today and can create a global brand image regarding their effectiveness in use which can affect the hospital's reputation.

Keywords: marketing, hospital, brand building
}

Korespondensi: Muhammad Fahriza

Email: iza_dr@yahoo.co.id 


\section{PENDAHULUAN}

Lebih dari 4,5 miliar orang di dunia menggunakan internet, dan jumlah pengguna media sosial di seluruh dunia telah melampaui angka 3,8 miliar pada awal tahun 2020 . Facebook dan Twitter merupakan alat media sosial yang populer. Pada kuartal kedua tahun 2020, Facebook memiliki lebih dari 2,7 miliar pengguna aktif bulanan. Pada kuartal pertama 2019, Twitter memiliki rata-rata 330 juta pengguna aktif bulanan di seluruh dunia. Manfaat utama media sosial untuk komunikasi kesehatan adalah aksesibilitas dan perluasan akses informasi kesehatan ke berbagai kelompok populasi, tanpa memandang usia, pendidikan, ras atau etnis, dan lokalitas. ${ }^{1,2} \mathrm{Jadi}$, banyak organisasi layanan kesehatan menggunakan media sosial.

Pada tahun 2014, sebanyak 94\% rumah sakit menggunakan media sosial dalam komunikasi pemasarannya. ${ }^{2}$ Di Amerika Serikat, 94,41\% rumah sakit memiliki halaman Facebook dan 50,82\% memiliki akun Twitter. Di Eropa Barat, sebanyak 67,0\% rumah sakit memiliki halaman Facebook dan 18,1\% memiliki akun Twitter. Penelitian sebelumnya melaporkan bahwa rumah sakit menggunakan media sosial untuk mengumumkan berita dan acara serta untuk mempromosikan diri dan kesehatan. Saat ini, dalam sistem layanan kesehatan, jumlah rumah sakit yang menggunakan media sosial meningkat drastis. ${ }^{1,2}$ Tujuan dari studi ini adalah untuk mengkaji penggunaan media sosial dalam bidang pemasaran di rumah sakit.

\section{METODE}

\section{Strategi Pencarian}

Kajian sistematis ini dilakukan pada artikel yang dipublikasi pada tahun 2016 hingga 2020 yang mengidentifikasi jenis platform dan hasil penting mengenai penggunaan media sosial dalam bidang pemasaran di rumah sakit. Pencarian artikel menggunakan kata kunci "social media" dikombinasikan dengan kata kunci "hospital" dan "marketing" atau "hospital marketing" dan melalui database pencarian Google Scholar dan PubMed. (Gambar 1)

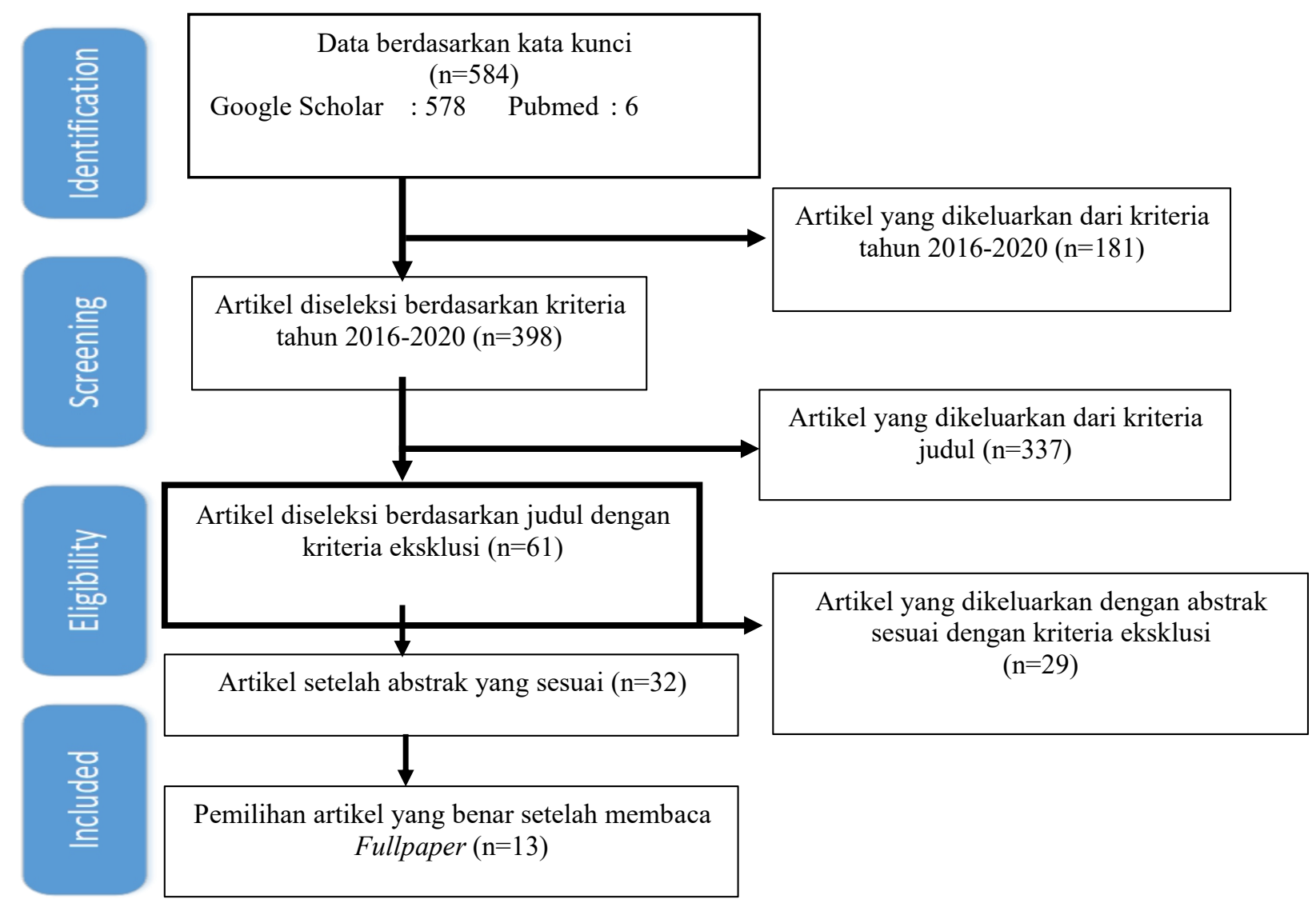

Gambar 1. Diagram Alur Pemilihan Artikel 


\section{Kriteria Kelayakan}

Untuk pemilihan artikel yang berkaitan dengan wilayah penelitian, kriteria inklusi yakni (1) penelitian yang dilakukan mengenai penggunaan media sosial dalam bidang pemasaran di rumah sakit selama 5 tahun terakhir, (2) semua penelitian deskriptif dan analitik dengan metodologi yang berbeda, dan (3) hanya studi yang berbahasa Inggris. Kriteria eksklusi yakni (1) penelitian tentang penggunaan media sosial yang terkait dengan area pelayanan lain, (2) penelitian tentang pemasaran terkait produk farmasi dan kesehatan masyarakat, dan (3) artikel yang teks lengkapnya tidak bisa untuk diakses.

\section{Proses Pengkajian}

Pencarian database dilakukan dengan menggunakan strategi pencarian khusus database. Artikel dengan kata "marketing", "social media", dan "hospital" pada judul dan abstraknya dipilih. Kemudian, artikel yang ganda diidentifikasi dan dihapus dari proses pengkajian. Setelah itu, kriteria inklusi dan eksklusi diterapkan. Daftar judul dari semua artikel yang dicari di database disiapkan. Daftar penelitian yang telah dipilih disaring untuk menentukan penelitian yang paling relevan, dan artikel yang tidak relevan ditolak. Evaluasi dan penyusunan judul abstrak serta identifikasi dan penghapusan artikel yang ganda dilakukan dengan menggunakan perangkat lunak Mendeley.

\section{Penilaian Kualitas}

Setelah artikel diunduh dan diekstraksi dalam database khusus, artikel tersebut dievaluasi menggunakan checklist analitik deskriptif. Artikel yang tidak mencantumkan syarat kualitas untuk pelaporan dieksklusi.

\section{Ekstraksi Data}

Setelah mengevaluasi kualitas artikel hasil ekstraksi, ada 13 artikel yang dipilih. Data yang dibutuhkan termasuk nama penulis dan tahun publikasi, waktu dan lokasi penelitian, jenis platform media sosial, desain penelitian, dan hasil penting diekstraksi dalam bentuk tabel.

\section{HASIL \\ Rangkuman dari Artikel yang Dikaji}

Setelah mengevaluasi artikel yang diekstraksi dan menyaring artikel berdasarkan relevansi dan kualitasnya, 13 artikel dipilih untuk dipelajari, hasilnya dapat dilihat pada (Tabel 1). Penelitian-penelitian ini dilakukan antara tahun 2016 hingga 2020 di berbagai belahan dunia.

\section{Tabel 1. Data Hasil Review Artikel}

\begin{tabular}{|c|c|c|c|c|c|c|}
\hline No. & Judul & $\begin{array}{c}\text { Penulis, } \\
\text { tahun }\end{array}$ & Negara & $\begin{array}{l}\text { Desain } \\
\text { Studi }\end{array}$ & $\begin{array}{c}\text { Jenis } \\
\text { Platform } \\
\text { Media } \\
\text { Sosial }\end{array}$ & Hasil \\
\hline 1 & $\begin{array}{l}\text { How U.S. } \\
\text { children's } \\
\text { hospitals use } \\
\text { social media }\end{array}$ & $\begin{array}{l}\text { Wong } \\
\text { dkk., } 2016^{3}\end{array}$ & $\begin{array}{l}\text { Amerika } \\
\text { Serikat }\end{array}$ & $\begin{array}{l}\text { Kualitatif } \\
\text { dan } \\
\text { kuantitatf }\end{array}$ & $\begin{array}{l}\text { Facebook, } \\
\text { Twitter, } \\
\text { YouTube, } \\
\text { Google+ } \\
\text { dan } \\
\text { Pinterest }\end{array}$ & $\begin{array}{l}\text { Adopsi media sosial oleh rumah sakit anak di } \\
\text { Amerika Serikat telah tersebar luas. Di luar } \\
\text { peran pemasaran secara tradisional, media } \\
\text { sosial dapat berfungsi sebagai kanal untuk } \\
\text { edukasi kesehatan, keterlibatan dengan } \\
\text { komunitas, termasuk manfaat komunitas }\end{array}$ \\
\hline 2 & $\begin{array}{l}\text { Social Media } \\
\text { Use of } \\
\text { Hospitals in } \\
\text { Terms of } \\
\text { Communicatio } \\
n \text { and Public } \\
\text { Relations }\end{array}$ & $\begin{array}{l}\text { ÇERÇI, } \\
2017^{4}\end{array}$ & Turki & $\begin{array}{l}\text { Kualitatif } \\
\text { dan } \\
\text { kuantitatf }\end{array}$ & $\begin{array}{l}\text { Facebook, } \\
\text { Twitter, } \\
\text { Foursquare } \\
\text { dan } \\
\text { YouTube }\end{array}$ & $\begin{array}{l}\text { Kesadaran terkait media sosial di rumah sakit } \\
\text { sedang mengalami pertumbuhan, begitu juga } \\
\text { dengan penggunaannya. Namun, rumah sakit } \\
\text { tersebut tidak terlibat aktif secara online } \\
\text { dengan konsumen di halaman Facebook. } \\
\text { Kurangnya keterlibatan ini dapat dievaluasi } \\
\text { sebagai hilangnya kesempatan untuk } \\
\text { meningkatkan layanan pelanggan, } \\
\text { meningkatkan kualitas perawatan, dan } \\
\text { membangun loyalitas. Hasil lainnya adalah } \\
\text { fakta bahwa penggunaan media sosial berbeda } \\
\text { antar negara secara signifikan. Selain itu, } \\
\text { meskipun rumah sakit tersebut mengadopsi } \\
\text { setidaknya satu platform media sosial, tingkat }\end{array}$ \\
\hline
\end{tabular}




\begin{tabular}{|c|c|c|c|c|c|}
\hline No. & Judul & $\begin{array}{c}\text { Penulis, } \\
\text { tahun }\end{array}$ & Negara & $\begin{array}{c}\text { Desain } \\
\text { Studi }\end{array}$ & $\begin{array}{c}\text { Jenis } \\
\text { Platform } \\
\text { Media } \\
\text { Sosial }\end{array}$ \\
\hline
\end{tabular}

3 The Use of Arif dan Indonesi Social Media Darmawa, a review as Hospital $2019^{5}$ Marketing

Hospital Smith,
Marketing and $2017^{6}$
Communicatio
ns Via Social
Media

\section{Correlations}

between

hospitals,

social media Arora,

presence and 2018

reputation

ranking score and

\section{Amerika Kuantitatif} Serikat

Triemstra, Amerika Poeppelma Serikat dan Serikat

Kuantitatif

Twitter, Facebook, dan Instagram

Kuantitatif

Twitter,
blogs,
wikis,
LINE, dan
Instagram

keaktifan mereka bervariasi bergantung pada platform tersebut.

Facebook Penggunaan media sosial mempengaruhi Youtube, reputasi rumah sakit karena terdapat tingkat Whatsapp, kepercayaan dan saling berbagi yang tinggi di Facebook komunitas media sosial, media sosial dapat Messenger, digunakan sebagai alat yang efektif untuk Wechat pemasaran rumah sakit. Sejauh mana media dan sosial masih efektif untuk pemasaran Instagram diperlukan penelitian di masa depan tentang peraturan kesehatan di masing-masing negara.

Facebook, Dalam memilih media sosial mana yang akan Twitter, digunakan, perusahaan perlu mengetahui YouTube, platform mana yang digunakan oleh Google+, pelanggan mereka atau kelompok sasaran blog/news, yang diinginkan. Sebagian besar rumah sakit Pinterest, menggunakan tiga platform media sosial dan berikut ini: Facebook, Twitter, dan YouTube. LinkedIn. Berbagai platform media sosial dapat digunakan untuk menjangkau orang-orang dengan demografi tertentu atau dengan kebutuhan dan minat tertentu. Temuan mengungkapkan terdapat beberapa perbedaan dalam penggunaan platform lainnya tergantung pada layanan rumah sakit.

Terdapat sebuah korelasi yang signifikan secara statistik antara beberapa metrik media sosial dan skor reputasi rumah sakit dan poin total (yaitu, peringkat keseluruhan). Asosiasi ini dapat menunjukkan bahwa reputasi rumah sakit dapat dipengaruhi oleh keberadaan media sosialnya atau reputasinya atau peringkat rumah sakit dapat mendorong pengikut media sosial.

Lebih sedikit rumah sakit dan klinik di Jepang yang menggunakan media sosial dibandingkan dengan negara lainnya. Media sosial terutama digunakan untuk berhubungan dengan masyarakat. Beberapa konten yang disebarluaskan oleh institusi medis dapat bertentangan dengan pedoman periklanan medis. Penelitian ini dapat menjadi referensi bagi institusi medis untuk memandu penggunaan media sosial dan dapat membantu meningkatkan iklan situs medis di Jepang.
Kualitatif dan kuantitatif
Facebook, Twitter, dan YouTube
Pertama, media sosial dapat meningkatkan pemasaran produk dan layanan wisata dengan memungkinkan pemasok melakukan bentuk komunikasi inovatif dengan pelanggan mereka dalam jarak geografis yang jauh. Namun, penelitian yang berfokus pada pemantauan dan evaluasi penggunaan media sosial untuk pemasaran jasa pariwisata masih terbatas. Kedua, menjelaskan perlunya keterlibatan 


\begin{tabular}{|c|c|c|c|c|c|}
\hline No. & Judul & $\begin{array}{c}\text { Penulis, } \\
\text { tahun }\end{array}$ & Negara & $\begin{array}{c}\text { Desain } \\
\text { Studi }\end{array}$ & $\begin{array}{c}\text { Jenis } \\
\text { Platform } \\
\text { Media } \\
\text { Sosial }\end{array}$ \\
\hline
\end{tabular}

8

$\begin{array}{lccc}\text { Use } & \text { of } & \text { Yang dkk., Taiwan } \\ \text { facebook } & \text { by } 2018^{9} \\ \text { hospitals } & \text { in } & \\ \text { taiwan: } & A & \\ \text { nationwide } & & \\ \text { survey } & & \end{array}$

9

Exploring the

use

Facebook as a

marketing and

branding tool

by hospital

foundations

10 The

Effectiveness

of Instagram Achadi,

as $\quad$ A 201911

Promotion

Media at Citra

Ananda

Maternal and

Child Health

Hospital

Patients

Visiting

Intention:

a dan Lubis,

Internal and

Social Media

Marketing in

Kambang

Jambi

Hospital a, Yacob

Kuantitatif Facebook

Kualitatif Facebook

Bélanger, $2019^{10}$

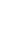

\section{Indonesi Kuantitatif Instagram a}

Indonesi Kuantitatif

a

\begin{tabular}{|c|c|c|c|}
\hline $\begin{array}{l}\text { Twitter } \\
\text { impact } \\
\text { building } \\
\text { reputed } \\
\text { hospital }\end{array}$ & $\begin{array}{r}s \\
\text { in }\end{array}$ & $\begin{array}{l}\text { Aguerreber } \\
\mathrm{e}, 2020^{13}\end{array}$ & $\begin{array}{l}\text { Amerika } \\
\text { Serikat }\end{array}$ \\
\hline
\end{tabular}

pelanggan dan membangun hubungan dalam pemasaran layanan wisata medis melalui platform media sosial karena keterlibatan pelanggan dianggap sebagai anteseden utama dari keterlibatan merek dan niat penggunaan merek.

Terlepas dari popularitas Facebook di kalangan masyarakat umum, sebagian besar rumah sakit di Taiwan tampaknya tidak memanfaatkan media sosial semacam ini dengan baik. Alasan penggunaan dan tidak menggunakan Facebook di pihak rumah sakit dan pasien perlu diteliti lebih lanjut.

Hasilnya diukur berdasarkan beberapa praktik terbaik pemasaran Facebook untuk menentukan implikasi praktis dan kesimpulan bagi yayasan rumah sakit. Secara keseluruhan, yayasan rumah sakit menyadari pentingnya mempersonalisasi pesan mereka, tetapi mereka jauh dari tolak ukur Facebook, termasuk Frekuensi Posting dan Jenis Media yang Digunakan.

Instagram memiliki efek substansial pada atribut 5A (Aware, Appeal, Ask, Act, dan Advocate) dari media promosi di Rumah Sakit Ibu dan Anak swasta.

Facebook, Website, Instagram dan Youtube

Kuantitatif Twitter
Pemasaran internal dibentuk dari dua dimensi yaitu kepuasan karyawan dan kepuasan pasien, pengaruh terhadap media sosial dan pengaruh terhadap niat kunjungan pasien. Pemasaran internal secara langsung mempengaruhi niat kunjungan pasien yang terdiri dari 4 dimensi yaitu kepentingan transaksional, refensi, preferensial dan eksplorasi. Media Sosial memediasi Pemasaran Internal dan berpengaruh signifikan terhadap Niat Kunjungan Pasien.

Rumah sakit yang tertarik untuk menggunakan Twitter secara efektif sebagai alat komunikasi perusahaan untuk inisiatif branding perlu melakukan refleksi strategis sebelum meluncurkan inisiatif apa pun di platform ini, meningkatkan integrasi Twitter dengan platform media sosial dan aplikasi seluler lainnya, dan memfasilitasi kolaborasi yang lebih baik antara profesional kesehatan dan komunikasi ahli. 


\begin{tabular}{|c|c|c|c|c|c|c|}
\hline No. & Judul & $\begin{array}{c}\text { Penulis, } \\
\text { tahun }\end{array}$ & Negara & $\begin{array}{l}\text { Desain } \\
\text { Studi }\end{array}$ & $\begin{array}{c}\text { Jenis } \\
\text { Platform } \\
\text { Media } \\
\text { Sosial }\end{array}$ & Hasil \\
\hline 13 & $\begin{array}{l}\text { How Turkish } \\
\text { Private } \\
\text { Hospitals use } \\
\text { Social media: } \\
\text { A Qualitative } \\
\text { Study }\end{array}$ & $\begin{array}{l}\text { İlgün dan } \\
\text { Uğurluoğl } \\
u, 2019^{14}\end{array}$ & Turki & Kualitatif & $\begin{array}{l}\text { Facebook, } \\
\text { Twitter, } \\
\text { dan } \\
\text { Instagram }\end{array}$ & $\begin{array}{l}\text { Institusi pelayanan kesehatan harus berhati- } \\
\text { hati saat menggunakan media sosial. Seperti } \\
\text { yang ditunjukkan oleh subjek penelitian, } \\
\text { penyalahgunaan media sosial karena sifat } \\
\text { layanan kesehatan dapat mempengaruhi } \\
\text { privasi pasien dan menyesatkan pasien. Selain } \\
\text { itu, kesalahan kecil di media sosial dapat } \\
\text { merusak citra lembaga pelayanan kesehatan, } \\
\text { dan juga dapat menimbulkan persaingan tidak } \\
\text { sehat akibat manipulasi. }\end{array}$ \\
\hline
\end{tabular}

Mengenai target populasi, sebagian besar penelitian menggunakan populasi di Amerika Serikat. Selain itu, metode penelitian yang paling sering digunakan dalam artikel yang dikaji adalah studi kuantitatif yang dipublikasikan paling banyak pada tahun 2019 . Studi dengan jumlah tipe platform media sosial yang dikasji lebih dari 1 macam lebih banyak daripada yang meneliti salah satu tipe platform saja dengan jenis platform media sosial yang paling sering diteliti adalah Facebook, yang diikuti dengan Twitter dan Instagram. Data lengkap variabel tersbut ditampilkan pada (Tabel 2).

Tabel 2. Karakter deskriptif dari Artikel yang Dikaji

\begin{tabular}{lr}
\hline Variabel & n (\%) \\
\hline Lokasi studi & \\
Amerika Serikat & $4(30,8 \%)$ \\
Indonesia & $3(23,1 \%)$ \\
Turki & $2(15,4 \%)$ \\
Negara lainnya & $4(30,8 \%)$ \\
Desain studi & \\
Kualitatif & $7(53,9 \%)$ \\
Kuantitatif & $2(15,4 \%)$ \\
Lainnya & $4(30,8 \%)$ \\
Jumlah tipe platform media sosial yang dikaji \\
1 macam & $4(30,8 \%)$ \\
$>1$ macam & $9(69,2 \%)$ \\
Jenis platform media sosial yang banyak diteliti \\
Facebook & $12(92, \%)$ \\
Twitter & $8(61,5 \%)$ \\
Instagram & $6(46,2 \%)$ \\
Tahun publikasi & \\
2016 & $1(7,7 \%)$ \\
2017 & $2(15,4 \%)$ \\
2018 & $3(23,1 \%)$ \\
2019 & $5(38,5 \%)$ \\
2020 & $2(15,4 \%)$ \\
\hline
\end{tabular}

Semua platform media sosial yang diteliti pada artikel-artikel yang dikaji, mencakup Facebook, Twitter, Instagram, YouTube, Google+, blog/news, Pinterest, dan LinkedIn. Media sosial tersebut masingmasing dideskripsikan dalam (Tabel 3).

\section{Tabel 3. Deskripsi dari platform media} sosial.

\begin{tabular}{|c|c|}
\hline $\begin{array}{l}\text { Media } \\
\text { Sosial }\end{array}$ & Deskripsi \\
\hline Facebook & $\begin{array}{l}\text { Pengguna membuat profil pribadi, } \\
\text { menambahkan pengguna lain sebagai } \\
\text { teman, dan bertukar pesan. Pengguna } \\
\text { dapat bergabung dengan grup pengguna } \\
\text { dengan minat yang sama. }\end{array}$ \\
\hline Twitter & $\begin{array}{l}\text { Pengguna mengirim dan membaca pesan } \\
\text { teks hingga } 140 \text { karakter. }\end{array}$ \\
\hline Instagram & $\begin{array}{l}\text { Pengguna mengedit dan mengunggah } \\
\text { foto dan video pendek melalui aplikasi } \\
\text { seluler. Pengguna dapat menambahkan } \\
\text { keterangan ke setiap unggahan mereka } \\
\text { dan menggunakan hashtag (tagar) dan } \\
\text { geotag lokasi untuk mengindeks } \\
\text { unggahan ini dan membuatnya dapat } \\
\text { dicari oleh pengguna lain di dalam } \\
\text { aplikasi. }\end{array}$ \\
\hline YouTube & $\begin{array}{l}\text { Situs web berbagi video tempat } \\
\text { pengguna dapat mengunggah dan } \\
\text { melihat video }\end{array}$ \\
\hline Google+ & $\begin{array}{l}\text { Facebook versi } \text { Google. } \\
\text { Google+Hangouts, sebuah fitur yang } \\
\text { memungkinkan berbagai jenis } \\
\text { komunikasi, yaitu dengan gabungan } \\
\text { pesan instan, pesan teks, panggilan } \\
\text { telepon internet, pesan video, dan } \\
\text { obrolan grup }\end{array}$ \\
\hline $\begin{array}{l}\text { Firm } \\
\text { blog/news }\end{array}$ & $\begin{array}{l}\text { Situs diskusi atau informasi. Blog adalah } \\
\text { salah satu bentuk jejaring sosial karena } \\
\text { sifat interaktifnya yang memungkinkan } \\
\text { pengunjung memberikan komentar. }\end{array}$ \\
\hline Pinterest & Situs web berbagi foto yang \\
\hline
\end{tabular}




\begin{tabular}{|c|c|}
\hline $\begin{array}{l}\text { Media } \\
\text { Sosial }\end{array}$ & Deskripsi \\
\hline & $\begin{array}{l}\text { memungkinkan pengguna membuat } \\
\text { koleksi gambar dengan tema seperti } \\
\text { acara, minat, atau hobi. Pengguna }\end{array}$ \\
\hline LinkedIn & $\begin{array}{l}\text { menjelajahi "pinboards" orang lain } \\
\text { Jejaring sosial untuk orang-orang yang } \\
\text { memiliki pekerjaan profesional }\end{array}$ \\
\hline
\end{tabular}

Berdasarkan struktur artikel yang dipelajari, penggunaan media sosial rumah sakit di berbagai negara dapat dibagi menjadi dua kategori: jenis platform media sosial dan efektivitasnya berupa hasil atau manfaat dari penggunaannya.

\section{PEMBAHASAN}

Dalam penelitian ini, dilakukan evaluasi terhadap 13 artikel terkait penggunaan media sosial dalam bidang pemasaran rumah sakit. Kajian sistematis ini menunjukkan pertumbuhan yang dramatis dari adanya sosial media di rumah sakit. Hal ini mengindikasikan suatu peningkatan nilai media sosial bagi rumah sakit terkait potensinya dalam meningkatkan pangsa pasar, keterlibatan dengan pasien, meningkatkan keuntungan, dan memajukan misi dalam kesehatan dan layanan kesehatan. Rumah sakit menggunakan platform media sosial yang berbeda untuk terhubung dengan pasien, tergantung pada jenis informasi yang ingin mereka tampilkan. Tetapi kebanyakan rumah sakit menggunakan lebih dari satu platform media sosial. Rumah sakit besar, nirlaba, swasta, rumah sakit di perkotaan, dan rumah sakit pendidikan cenderung menggunakan banyak platform dan mendapatkan timbal balik berupa lebih banyak like, follower, check-in, dan ulasan., Penggunaan berbagai platform ditujukan untuk orang-orang dengan demografi tertentu, atau dengan kebutuhan dan minat tertentu. Beberapa fitur media sosial pada umumnya memiliki sistem yang terintegrasi, sehingga media sosial tersebut saling terhubung. Studi tersebut menunjukkan bahwa Facebook adalah platform yang paling disukai, diikuti oleh Twitter dan Instagram.

Rumah sakit tertentu secara aktif mengelola media sosial mereka dan melakukan upaya ekstra dengan menyediakan staf tambahan untuk memperbarui konten dan menanggapi komentar di halaman. Hal ini dapat menarik lebih banyak perhatian dari pengguna media sosial, meningkatkan kualitas informasi dan memperkuat hubungan dengan pasien, penyedia layanan, pembuat kebijakan, dan komunitas online mereka. Informasi yang dibagikan di media sosial rumah sakit termasuk pengumuman atau rekaman acara untuk menarik lebih banyak peserta dan pasien, informasi kesehatan, berita dan kontribusi atau pencapaian rumah sakit. ${ }^{6,9,15}$ Penggunaan media sosial sebagai alat pemasaran dapat dijelaskan sebagai berikut: Dalam perannya sebagai Integrated Marketing Communication (IMC), media sosial mampu menjalankan fungsi promotion mix (gabungan dari berbagai jenis promosi) secara terintegrasi, bahkan hingga proses transaksi berlangsung. Dimana ketika pelanggan telah menjadi pengguna sosial media yang masuk dalam keanggotaan akun media sosial milik rumah sakit, maka secara otomatis perusahaan dapat menjalin komunikasi yang berkelanjutan. ${ }^{15}$ Pendekatan yang berhasil dapat mengarah pada pengembangan dan pemeliharaan hubungan perusahaan-pelanggan yang baik. Mereka mempromosikan brand (merek) perusahaan kepada calon klien, meyakinkan mereka yang memiliki ketertarikan dalam mencoba produk atau jasa/ pelayanan. Media sosial juga sering dijadikan barometer popularitas, karena dapat memuat topik yang paling banyak dibicarakan di media sosial (trending topic) menggunakan fasilitas hashtag (\#) dan didukung fasilitas retweet dan konversi secara terbuka. Semakin banyak member yang menggunakan hashtag yang dibuat, semakin besar kemungkinannya untuk menjadi tren. Akibat terlalu seringnya, media sosial ini menjadi rujukan utama para pasien. ${ }^{5}$ Faktor pendukung lain seperti kemudahan mengakses, kemudahan berinteraksi, dan populernya media sosial yang digunakan menjadi alasan dibalik dipilihnya media sosial yang efektif untuk memasarkan produk. Sebagian besar rumah sakit memilih Facebook dan Twitter untuk menarik konsumen dan mengarahkan mereka ke media sosial lain, seperti blog, forum, atau situs web. Selain karena Facebook dan Twitter lebih populer dan bisa berinteraksi langsung, juga karena media sosial ini sudah menjadi aplikasi wajib yang tersedia di telepon seluler dan mudah dioperasikan. ${ }^{6,9,15}$

Media sosial memungkinkan pasien untuk berkontribusi dalam pengetahuan, pengalaman pribadi, dan umpan balik tentang operasional rumah sakit. Hal ini dapat mengarah pada layanan kesehatan yang lebih 
berpusat pada pasien, yang sebagai gantinya menghasilkan peningkatan kebahagiaan pasien. Perasaan bahagia itu bisa berubah menjadi kesetiaan terhadap rumah sakit. Pelanggan setia lebih cenderung menjadi brand advocate. ${ }^{6}$ Media sosial dapat menjadi alat yang berguna untuk memperluas komunikasi dengan pasien dan komunitas pada umumnya dan berbagi budaya rumah sakit dengan basis yang lebih besar dari orang-orang yang berpikiran sama. Dengan kekuatan baru ini, muncul platform dengan tanggung jawab tinggi yang meskipun memiliki potensi dalam menjangkau jutaan penonton dan pembaca, tapi juga berpotensi penyalahgunaan yang dapat membahayakan privasi pasien dan membahayakan rumah sakit. ${ }^{15}$ Hal tersebut merupakan kondisi yang perlu ditangani dengan ekstra hati-hati karena dari beberapa negara yang mengatur cara rumah sakit atau layanan kesehatan mengiklankan konten medis, sebagian dari mereka belum secara spesifik mengatur bagaimana media sosial digunakan dalam bidang medis.

\section{KESIMPULAN}

Hasil kajian penelitian ini menunjukkan efektivitas dan pentingnya penggunaan media sosial. Platform media sosial telah menjadi salah satu keharusan bagi suatu organisasi untuk bersaing dalam tren pemasaran dan promosi saat ini serta mampu menciptakan brand image secara global. Berada dalam lingkungan komunikasi berbasis internet yang menghilangkan hierarki antar individu dan batas antar negara telah menjadi kebutuhan bagi institusi yang bergerak di bidang kesehatan seperti institusi umum lainnya. Jelas bahwa banyak rumah sakit saat ini tidak hanya menggunakan satu, tetapi beberapa platform media sosial. Penggunaan media sosial mempengaruhi reputasi rumah sakit. Dan karena ada tingkat kepercayaan dan sharing yang tinggi di komunitas media sosial, media sosial bisa digunakan sebagai strategi pemasaran rumah sakit. Dengan pemantauan dan pengawasan yang konstan serta komitmen untuk peningkatan kualitas, rumah sakit dapat secara efektif menggunakan aplikasi media sosial untuk pemasaran di samping edukasi. Namun untuk menyelidiki sejauh mana media sosial efektif untuk pemasaran membutuhkan studi lebih lanjut mengenai peraturan kesehatan masing-masing negara.

\section{DAFTAR PUSTAKA}

1. Sugawara Y, Murakami M, Narimatsu H. Use of Social Media by Hospitals and Clinics in Japan: Descriptive Study. JMIR Med Informatics. 2020;8(11):e18666.

2. MacDonald I. Hospitals embrace social media, but have yet to realize its full benefits | FierceHealthcare [Internet]. 2014 [cited 2020 Dec 31]. Available from:

https://www.fiercehealthcare.com/healt hcare/hospitals-embrace-social-mediabut-have-yet-to-realize-its-full-benefits

3. Wong CA, Ostapovich G, KramerGolinkoff E, Griffis H, Asch DA, Merchant RM. How U.S. children's hospitals use social media: A mixed methods study. Healthcare. 2016;4(1):15-21.

4. ÇERÇİ ÜÖ. Social Media Use of Hospitals in Terms of Communication and Public Relations. Turkish Online J Des Art Commun. 2017;7(2):192-202.

5. Arif UF, Darmawan ES. The Use of Social Media as Hospital Marketing. Proc Int Conf Appl Sci Heal. 2019;(4):902-8.

6. Smith KT. Hospital Marketing and Communications Via Social Media. Serv Mark Q [Internet]. 2017;38(3):187-201. Available from: https://doi.org/10.1080/15332969.2017. 1363518

7. Triemstra JD, Poeppelman RS, Arora VM. Correlations between hospitals' social media presence and reputation score and ranking: Cross-sectional analysis. $\mathrm{J}$ Med Internet Res. 2018;20(11):1-5.

8. John S, Larke R, Kilgour M. Applications of social media for medical tourism marketing: an empirical analysis. Anatolia [Internet]. 2018;29(4):553-65. Available from: https://doi.org/10.1080/13032917.2018. 1473261

9. Yang PC, Lee WC, Liu HY, Shih MJ, Chen TJ, Chou LF, et al. Use of facebook by hospitals in taiwan: A nationwide survey. Int $\mathrm{J}$ Environ Res 
Public Health. 2018;15(6).

10. Bali S, Bélanger $\mathrm{CH}$. Exploring the use of Facebook as a marketing and branding tool by hospital foundations. Int $\mathrm{J}$ Nonprofit Volunt Sect Mark. 2019;24(3):1-10.

11. Marliani L, Achadi A. The Effectiveness of Instagram as A Promotion Media at Citra Ananda Maternal and Child Health Hospital, Ciputat, Banten. 2019;130-6.

12. Yulhasmida, Yacob S, Lubis TA. Patients Visiting Intention: a Perspective of Internal and Social Media Marketing in Kambang Jambi Hospital. J Bus Stud Mangement Rev. 2019;2(2):143-53.

13. Aguerrebere PM. Twitter' $\mathrm{s}$ impact in building reputed hospital brands in USA. 2020;14:63-77.

14. İlgün $G$, Uğurluoğlu Ö. How Turkish Private Hospitals use Social media: A Qualitative Study. J Soc Serv Res. 2019;45(1):34-43.

15. Siswanto T. Optimalisasi Sosial Media sebagai Media Pemasaran Usaha Kecil Menengah. J Liq [Internet]. 2013 [cited 2020 Dec 31];2(1):80-6. Available from: http://www.ojs.itbad.ac.id/index.php/LQ/article/view/134 